\title{
Rancang Bangun Aplikasi E-Culture Topeng Cirebon Dengan Augmented Reality Berbasis Android
}

\author{
Agus Ma'sum ${ }^{1}$, Sodik Kirono*2, Handaru ${ }^{3}$ \\ ${ }^{1,3}$ Teknik Informatika, STIKOM Poltek Cirebon, Indonesia. \\ ${ }^{2}$ Teknik Informatika, Universitas Muhadi Setiabudi Brebes, Indonesia. \\ e-mail corresponden: *kironosodik@gmail.com
}

\begin{abstract}
Abstrak
Indonesia terdiri dari berbagai suku bangsa yang kaya akan keanekaragaman budaya. Salah satunya adalah budaya kesenian dari Cirebon Jawa barat yaitu kesenian topeng Cirebon. Topeng Cirebon merupakan budaya Cirebon yang saat ini kurang dikenal secara mendalam oleh masyarakat, masyarakat hanya mengetahui bentuk topeng Cirebon tanpa mengetahui nama, jenis, dan arti yang terkandung pada setiap topeng Cirebon. Saat ini topeng Cirebon sudah digantikan oleh hiburan - hiburan tarian modern dan hiburan musik dangdut yang saat ini sedang marak. Perkembangan teknologi yang sangat pesat membawa teknologi baru yang saat ini sedang berkembang yaitu augmented reality. Augmented reality adalah penggabungan antara objek dunia nyata dan virtual. Teknologi ini di terapkan pada aplikasi e-Culture topeng Cirebon, augmented reality diterapkan dengan menggunakan teknik face detection, dengan teknik ini kamera akan mendeteksi wajah dan menampilkan objek topeng Cirebon. Tujuan dari penelitian ini adalah untuk memudahkan masyarakat dalam mengenali dan mempelajari kebudayaan topeng Cirebon. Pembangunan aplikasi e-Culture ini menggunakan software unity 3D, 3D Studio Max dan library XZIMG. Hasil dari penelitian ini berhasil membangun aplikasi e-Culture sesuai dengan kebutuhan pengguna aplikasi. Dengan diterapkannya aplikasi ini mampu meningkatkan minat masyarakat dalam melestarikan dan menjaga kesenian topeng Cirebon serta memudahkan masyarakat dalam mengenali budaya topeng Cirebon.
\end{abstract}

Kata kunci-Augmented reality, e-Culture, Topeng Cirebon.

\begin{abstract}
Indonesia consists of various ethnic groups that are rich in cultural diversity. One of them is the art culture from Cirebon, West Java, namely Cirebon mask art. Cirebon Mask is a Cirebon culture which is currently less well known by the community, the community only knows the shape of the Cirebon mask without knowing the name, type, and meaning contained in each Cirebon mask. At present the Cirebon mask has been replaced by entertainment modern dance entertainment and dangdut music entertainment which is currently rife. Rapid technological development brings new technology that is currently developing, namely augmented reality. Augmented reality is a combination of real and virtual world objects. This technology is applied to the Cirebon mask e-Culture application, augmented reality is applied using face detection techniques, with this technique the camera will detect faces and display Cirebon mask objects. The purpose of this study is to facilitate the public in recognizing and studying Cirebon mask culture. The development of this e-Culture application uses unity $3 D$ software, 3D Studio Max and XZIMG library. The results of this study succeeded in building an e-Culture application in accordance with the needs of application users. With the application of this application is able to increase the interest of the community in preserving and maintaining the art of Cirebon mask and facilitate the public in recognizing Cirebon mask culture.
\end{abstract} Keywords-Augmented reality, e-Culture, Topeng Cirebon.

Submitted: 15 April 2019, Accepted: 29 April 2019, Published: Mei 2019 ISSN: 2685-4902 (online), Website: http://jurnal.umus.ac.id/index.php/intec 


\section{PENDAHULUAN}

Bangsa Indonesia terdiri dari berbagai suku bangsa yang memiliki keanekaragaman budaya. Keanekaragaman budaya di Indonesia dapat dilihat dari berbagai ritual masyarakat dan kesenian tradisional di berbagai daerah yang mempunyai ciri khas masing-masing, salah satunya adalah ciri khas dari kesenian jawabarat yaitu seni tari.Tari atau tarian merupakan salah satu ekspresi jiwa seni manusia yang diungkapkan melalui gerak-gerak ritme yang indah. Salah satunya adalah seni tari topeng Cirebo yang mempunyai ciri khas dan makna tarian sesuai dengan topeng yang digunkan oleh sang penari. Tari topeng merupakan karya seni tradisional daerah yang tumbuh dan berkembang cukup lama di cirebon, tari topeng cirebon memiliki banyak ragam dan mengalami perkembangan dalam hal gerakan, maupun cerita yang ingin disampaikan. Kesenian tari topeng Cirebon ini masih kurang dikenal oleh masyarakat lokal maupun luar, beberapa masyarakat hanya mengetahui bentuk atau rupanya saja tetapi belum mengetahui nama ataupun arti dari setiap jenis topeng cirebon. Menurut mimi tumus sangat sulit sekali menjaga dan melestarikan tari topeng cirebon [1]. Tari topeng kurang dikenal karena sudah jarang diadakannya pentas tari topeng cirebon sebab sudah di gantikan oleh tarian-tarian modern sperti break dance dan hiburan lainnya seperti musik dangdut. Hal tersebut juga menyebabkan semakin sedikitnya pengrajin topeng cirebon yang berada di daerah cirebon karena kurang di apresiasi wisatawan yang berkunjung ke cirebon dan mahalnya harga souvenir topeng cirebon. Mahalnya topeng cirebon menurut pengamat seni dan budaya Cirebon Made Casta karena dalam proses pembuatannya berbeda dengan kerajinan topeng yang ada di daerah lain, pengrajin mempertimbangkan proses pencapaian dari sebuah karakter topeng yang membuat mahal.

Pekembangan yang sangat cepat telah membawa dunia memasuki era baru yang lebih cepat, salah satunya adalah teknologi augmented reality. Teknologi augmented reality merupakan teknologi yang dapat menggabungkan dunia nyata dengan dunia virtual dan di tampilkan dalam waktu real time. Augmented reality ini dapat dimanfaatkan untuk media pengenalan topeng cirebon yang dapat menampilkan objek topeng cirebon, dengan teknologi ini diharapkan dapat meningkatkan daya tarik masyrakat terhadap kesenian tradisional topeng Cirebon ini. Penelitian mengenai augemted reality mengenai budaya pernah dilakukan untuk proses pengenalan benda cagar budaya, menurutnya implementasi AR pada pengenalan benda cagar budaya dapat dapat dengan jelas dilihat oleh pengguna hasil visualisasi oleh teknologi AR. Selain itu dengan teknologi AR dapat meningkatkan persepsi dan interaksi pengguna dengan dunia nyata. Dengan tiga karakteristik yang dimiliki oleh AR, yaitu interaktif, real time dan obyek 3 dimensi, AR dapat menjadi teknologi interaktif yang dapat digunakan sebagai sarana pengenalan benda cagar budaya kepada masyarakat[2]. Selain itu AR juga pernah digunakan sebagai media pendukung untuk pembelajaran pengenalan rumah adat yang ada di Indonesia bagi siswa $\mathrm{SD}$, menurutnya dengan menggunakan AR maka pembelajaran dapat lebih aplikatif melalui visualisasi dalam bentuk AR[3].

Augmented reality menurut Abbas Abdoli Sejzi Augmented reality adalah pandangan langsung atau tidak langsung pada lingkungan nyata yang bagian-bagiannya ditambah melalui umpan balik sensorik buatan komputer seperti informasi audio, video, visual, atau GPS [4]. Augmented reality atau AR adalah suatu lingkungan yang memasukkan objek virtual $2 \mathrm{D}$ atau 3D kedalam lingkungan yang nyata. Augmented reality adalah teknologi yang menampilkan objek virtual berbentuk 2D atau 3D ke dalam lingkungan nyata yang mana pengguna bisa berinteraksi langsung dengan objek dan berjalan dalam waktu nyata (real time) yang didukung dengan sesnsor buatan komputer seperti informasi audio, video, visual atau GPS. Ilustrasi augmented reality pada Gambar 1 menjelaskan bahwa perangkat smartphone melakukan scan terhadap objek marker baik berupa gambar atau objek sekitar ketika objek terdeteksi akan menampilkan objek visual sesuai marker yang di scan yang ditampilkan di dunia nyata atau di sekitar marker diletakan. 


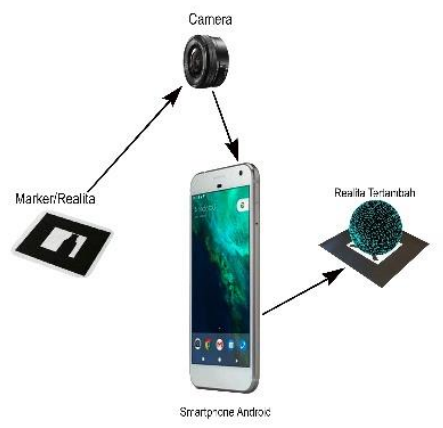

\section{Gambar 1 Ilustrasi Augmented Reality}

Menurut Dirk dan Esmans dalam jurnal Strategi Pembangunan e-Culture di Indonesia, 2016. e-Culture (Electronic Culture) mengacu pada hubungan antara teknologi informasi dan komunikasi dan media digital di satu sisi, dan produksi, konsumsi seni dan budaya. Dengan keluarnya media digital di sektor seni dan budaya menciptakan produk seni baru dan kemungkinan baru untuk produksi pengarsipan, presentasi seni dan produk budaya[5]. Tari topeng Cirebon adalah salah satu kesenian yang berasal dari daerah Cirebon, termasuk Subang, Indramayu, Jati barang, Majalengka, Losari dan Brebes. Disebut tari topeng karena sang penari menggunakan topeng saat menari. Tari topeng sendiri memilik banyak ragam dan terus berkembang gerakannya sesuai cerita yang ingin di sampaikan oleh penari. Terdapat lima jenis dan karakter tari topeng seperti panji, samba, rumyang, tumenggung dan kelana, adapun arti dari kelima jenis topeng Cirebon yaitu[6]

\section{a. Topeng Panji}

Topeng panji merupakan sebuah penggambaran dari sebuah jiwa yang halus.

\section{b. Topeng Samba}

Topeng samba merupakan sebuah penggambaran dari sebuah jiwa yang sedang tumbuh.

\section{c. Topeng Rumyang}

Topeng rumyang merupakan penggambaran dari jiwa manusia yang sudah melepaskan nafsu duniawinya dan menjadi manusia yang harum.

\section{d. Topeng Temenggung}

Topeng temenggung merupakan sebuah penggambaran dari sebuah jiwa yang sudah dewasa.

e. Topeng Kelana

Topeng kelana merupakan sebuah penggambaran dari jiwa manusia yang sudah melepaskan nafsu duniawinya dan menjadi manusia yang harum.

\section{METODE PENELITIAN}

Alur penelitian dapat di lihat pada Gambar 2 Penelitian dimulai dengan analisis masalah. Selanjutnya di lakukan pengumpulan data kemudian mendengarkan kebutuhan pengguna, membangun aplikasi prototipe sesuai keinginan pengguna. Tahap pengujian aplikasi prototipe yang dilakukan oleh pengguna untuk mengetahui hasilnya, setelah itu di lakukan evaluasi untuk mengetahui keberhasilan atau kegagalan pada tahap perancangan perangkat lunak.

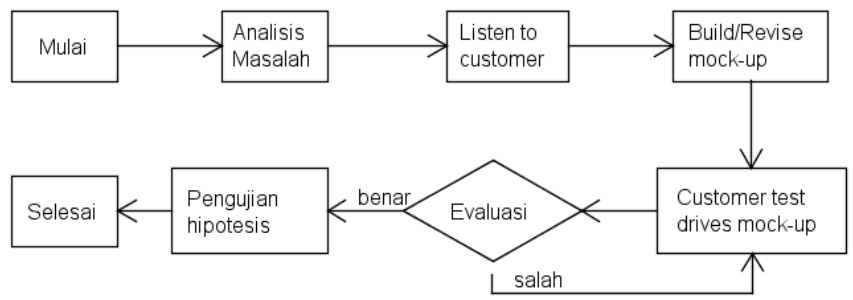

Gambar 2 Alur Penelitian 


\section{a. Analisis Masalah}

Analisis masalah dilakukan untuk mengetahui masalah apa yang terjadi pada kesenian topeng Cirebon dan mencari solusi untuk mengatasi permasalahan yang terjadi.

b. Listen to customer

1) Kebutuhan antar muka

Pada tahap ini akan dilakukan pengumpulan kebutuhan perangkat lunak dengan menggunakan teknik wawancara dan observasi. Adapun hasil dari tahap ini disajikan dalam bentuk narasi dan DFD dengan menggunakan software astah profesional.

2) Kebutuhan Data

Pada tahap ini akan dilakukan pengumpulan kebutuhan data, kebutuhan data di dapat setelah melakukan wawancara dan observasi pada Dinas Kebudayaan, Masyarakat, dan Sanggar tari topeng Cirebon. Setelah mendapat data yang dibutuhkan akan disajikan dalam bentuk narasi.

3) Kebutuhan Perangkat Keras

Kebutuhan minimum perangkat keras untuk pengembangan aplikasi yang di bangun sebagai berikut:

1. Sistem operasi Windows 10

2. CPU AMD A12-9700P RADEON 7

3. GPU AMD Radeon(TM) R7 Graphics

4. RAM $8.0 \mathrm{~GB}$

5. V-RAM 2.0 GB

Kebutuhan minimum perangkat keras untuk implementasi aplikasi yang dibangun sebagai berikut:

1. Sistem operasi Android Lolipop

2. CPU Quad Core $1.3 \mathrm{GHz}$ Cortex-A7

3. GPU Mali-T720

4. Kamera 5 Megapixel

5. Layar 4.7 inches

\section{c. Build/Revise Mock-up}

1) Pembangunan Prototipe

Pada tahap pembangunan prototipe peneliti menggunakan software unity 3D untuk membangun aplikasi $e$-culture topeng Cirebon dan menggunakan library XZIMG yaitu library untuk mendeteksi wajah. Selanjutnya menggunakan software 3D Studio Max 2012 untuk membuat desain 3D topeng Cirebon.

\section{2) Desain Prototipe}

Bagian desain dibuat berdasarkan kebutuhan antar muka yaitu dibuat dengan desain yang familiar dan mudah di gunakan oleh pengguna aplikasi. Untuk alur aplikasi dapat di lihat pada Gambar 3 Alur aplikasi e-culture topeng Cirebon.

Alur aplikasi dimulai dengan splash screen dan loading selanjutnya masuk ke menu utama dari aplikasi e-Culture, di dalam home terdapat menu topeng kamera, menu ini adalah menu utama dari aplikasi ini yang menerapkan teknologi augmented reality face detection topeng Cirebon. Selanjutnya ada menu toko budaya dan sanggar seni yang menginfokan toko yang menjual topeng-topeng Cirebon dan sanggar-sanggar yang fokus terhadap kesenian topeng Cirebon. 


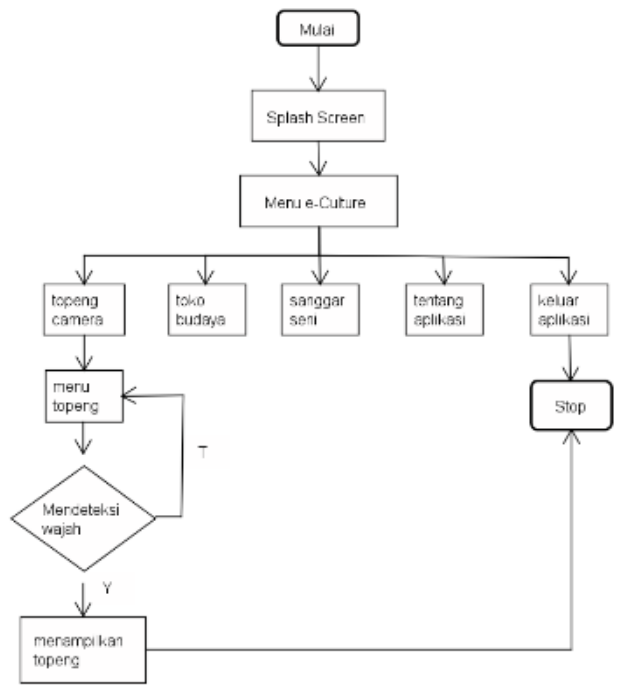

Gambar 3 Alur e-Culture

d. Customer Test Drives Mock-up

Pada tahap pengujian dilakukan pengujian dengan blackbox teknik error guessing. Rancangan tabel pengujian dapat dilihat pada Tabel 1 Pengujian Error Guessing.[7]

Tabel 1 Pengujian error guessing

\begin{tabular}{|l|l|l|l|c|c|l|}
\hline No. & Sub & Prosedur & Input & $\begin{array}{c}\text { Hasil } \\
\text { diharapkan }\end{array}$ & $\begin{array}{c}\text { Hasil } \\
\text { Sebenerarnya }\end{array}$ & Kesimpulan \\
\hline & & & & & & \\
\hline & & & & & & \\
\hline
\end{tabular}

\section{e. Evaluasi}

Evaluasi dilakukan pada hasil pengujian dengan kriteria evaluasi berdasarkan pengujian error guessing. Aplikasi topeng e-Culture dikatakan berhasil jika $90 \%$ fungsi aplikasi berjalan dengan baik dan jika masih terdapat masalah maka akan dilakukan perbaikan dan jika sudah lebih dari $90 \%$ berhasil maka $10 \%$ nya akan dilakukan untuk maintenance.

\section{f. Pengujian Hipotesis}

Pengujian hipotesis dilakukan dengan mengajukan pertanyaan dalam bentuk interview guide ke sepuluh responden secara purposive sampling[8], target responden adalah masyarakat umum cirebon. Tujuan dari pengujian ini untuk mengetahui apakah aplikasi $e$-Culture topeng Cirebon dapat memudahkan masyarakat dalam mengenali budaya topeng Cirebon.

Hasil dari penelitian ini akan berbentuk deskripsi kesimpulan yang didapat dari interview responden. Hasil dari interview akan diolah dan di analisis, dengan menganalisis dari setiap jawaban kemudian setiap jawaban akan di sajikan dalam bentuk tabel setelah itu akan di simpulkan setiap pertanyaannya. Untuk pertanyaan yang diajukan kepada responden dapat dilihat pada lampiran.

\section{HASIL DAN PEMBAHASAN}

\section{a. Hasil dan Pembahasan}

\section{1) Analisis Masalah}

Berdasarkan analisis budaya kesenian topeng Cirebon kurang di kenal karena sulitnya melestarikan kesenian topeng Cirebon di era globalisasi ini. Banyak masyarakat yang hanya mengenal beberapa jenis topeng saja dari lima jenis topeng yang ada serta tidak diketahuinya arti dari masing-masing karakter topeng yang meiliki arti tersendiri. 
Selanjutnya kurang minatnya wisatawan terhadap topeng Cirebon sebagai oleh-oleh karena harganya yang sangat mahal, hal itu karena minimnya pengrajin topeng dan sedikitnya generasi penerus pengrajin topeng Cirebon. Berdasarkan analisis tersebut sehingga dibutuhkan media untuk melestarikan kesenian topeng Cirebon yaitu dengan membuat aplikasi e-Culture topeng Cirebon sebagai aplikasi untuk mengatasi permasalahan yang terjadi.

\section{b. Listen to customer}

Berikut adalah hasil dari wawancara yang dilakukan pada dinas kebudayaan, sanggar topeng Cirebon, masyarakat dan wisatawan. Hasil wawancara yang dilakukan pada dinas kebudayaan sebagai berikut:

1) Kebudayaan Topeng Cirebon sangat berkembang di Cirebon banyak yang belajar tari topeng dari semua kalangan mulai dari anak sekolah dasar sampai mahasiswa.

2) Mempromosikan dengan cara membawa souvenir topeng Cirebon ke dalam acara di luar Cirebon dan dengan cara membuat artikel-artikel tentang kesenian topeng Cirebon dan di publish ke web resmi dari dinas kebudayaan.

3) Hanya ada beberapa sanggar yang fokus terhadap kesenian topeng Cirebon di antaranya di daerah Selangit, Losari, Tegal Wangi.

4) Dinas sangat memperhatikan toko souvenir kebudayaan Cirebon namun hanya ada satu toko yang mengkhususkan kesenian topeng Cirebon yang berlokasi di daerah Sunyaragi Cirebon.

Hasil wawancara yang dilakukan pada sanggar topeng Cirebon sebagai berikut:

1) Masih banyak peminat yang ingin belajar tari topeng Cirebon pada sangar, sanggar juga memberi latihan ke setiap sekolah-sekolah.

2) Memperkenalkan topeng Cirebon dengan cara belajar seperti di sekolah yaitu hanya menyampaikan materi.

3) Untuk pementasan tari topeng Cirebon sudah sangat jarang karena bersaing dengan hiburan-hiburan masa kini seperti musik dangdut dan lainnya. Untuk setiap pentas tari topeng hanya sebagai hiburan pembuka acara saja lain hal nya jika acara tersebut adalah acara khusus tentang kebudayaan Cirebon tari topeng akan di sajikan dengan semua tari topeng Cirebon yang ada lima jenis.

4) Untuk jenis topeng Cirebon ada lima jenis topeng Cirebon di antaranya di mulai dari:

a) Topeng Panji yang menggambarkan manusia yang baru lahir.

b) Topeng Samba yang menggambarkan seorang remaja.

c) Topeng Rumyang yang menggambarkan manusia yang sedang mencari jati diri.

d) Topeng Temenggung yang menggambarkan manusia yang menjadi abdi negara.

e) Topeng Kelana yang menggambarkan angkara murka.

Hasil wawancara yang dilakukan pada masyarakat Cirebon sebagai berikut:

1) Kebudayaan Cirebon yang di ketahui hanya batik dan topeng Cirebon.

2) Pernah menyaksikan topeng Cirebon di sekolah acara pentas seni sekolah dan di stadion rangga jati acara HUT Cirebon.

3) Hanya mengetahui jenis topeng yang warna merah dan putih dan namanya tidak tahu.

4) Tidak tahu arti dari setiap topeng Cirebon.

Hasil wawancara yang dilakukan pada masyarakat Cirebon sebagai berikut:

1) Tidak mengetahui kebudayaan Cirebon.

2) Pernah menyaksikan tari topeng Cirebon.

3) Hanya tau satu jenis topeng Cirebon yang berwarna merah ada saat menyaksikan tari topeng Cirebon.

4) Tidak mengetahui arti dari topeng Cirebon 


\section{Data Flow Diagram}

Kebutuhan fungsional dari apilaksi yang sudah di sebutkan sebelumnya akan digambarkan dalam bentuk data flow diagram. Data flow diagram dapat di lihat pada Gambar 4 dan Gambar 5.

1. DAD Level 0

2. DAD Level 1

Setelah di gambarkan dalam bentuk data flow diagram level 0 atau context diagram selanjutnya akan di gambarkan dalam bentuk data flow diagram level 1 yang dapat di lihat pada Gambar 5.

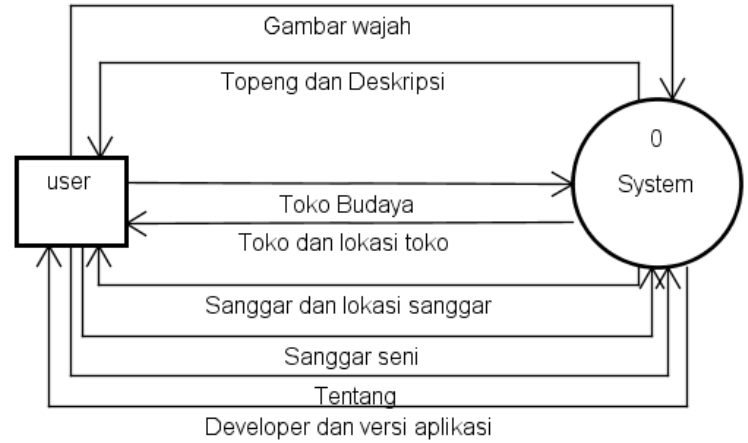

Gambar 4 Data Flow Diagram Level 0

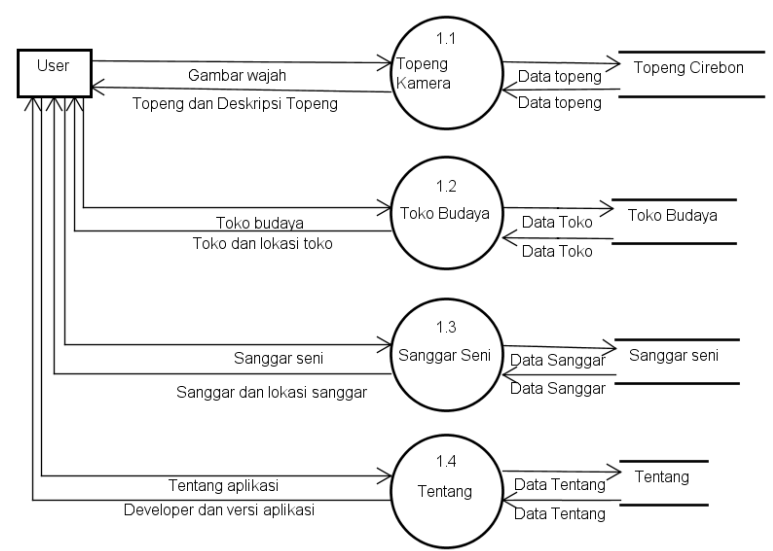

Gambar 5 Data Flow Diagram Level 1

\section{Flowchart}

Alur dari data flow diagram level 1 akan di gambarkan secara rinci dalam bentuk flowchart sebagai berikut:

\section{a) Flowchart Topeng Kamera}

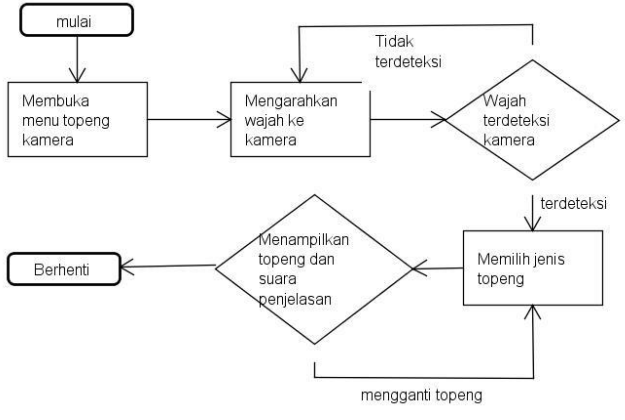

b) Flowchart Toko Budaya

Gambar 6 Flowchart Topeng Kamera 


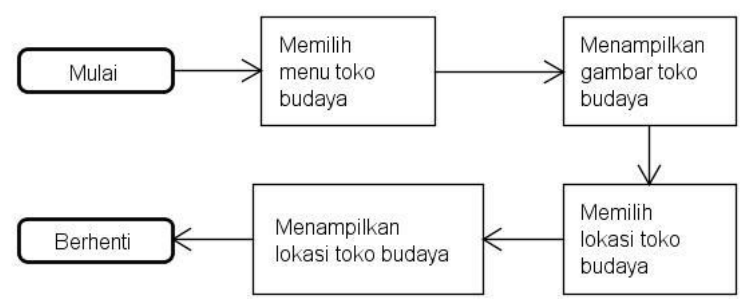

Gambar 7 Flowchart Toko Budaya

c) Flowchart Sanggar Seni

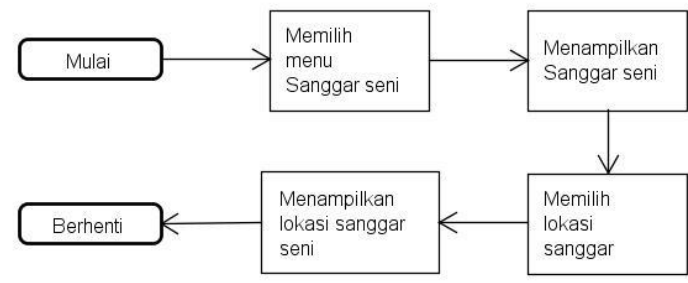

Gambar 8 Flowchart Sanggar Seni

\section{d) Flowchart Tentang}

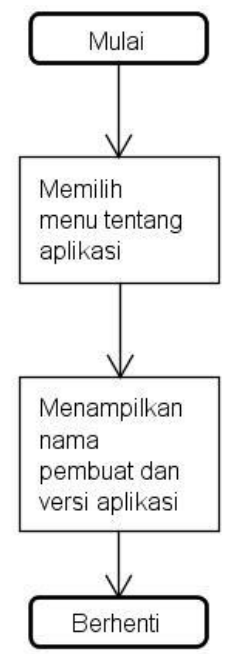

Gambar 9 Flowchart Tentang Aplikasi

\section{Build/Revise Mock-up}

Setelah merancang dan membangun aplikasi e-Culture topeng Cirebon beserta pengimplementasian augmented reality terhadap aplikasi e-Culture topeng Cirebon. Hasil perancangan mock-up awal untuk tampilan splash screen dapat dilihat pada Gambar 10. Pada splash screen terdapat logo e-Culture yang dibalut dengan motif mega mendung karena bertujuan memberi ciri bahwa aplikasi $e$-Culture ini akan berisi kebudayaan Cirebon.

Setelah splash screen maka akan menampilkan tampilan mock-up loading dapat dilihat pada Gambar 11. Pada mock-up loading terdapt logo e-Culture dan di tambahkan dengan gambar penari topeng Cirebon yang bertujuan aplikasi e-Culture ini akan berisi kebudayaan Topeng Cirebon dan memberikan kesan menarik untuk pengguna ketika membuka aplikasi. Rancangan awal mock-up selanjutnya adalah tampilan home yang dapat dilihat pada Gambar 12. Tampilan ini terdapat menu aplikasi di antaranya menu topeng kamera, menu toko budaya, menu sanggar seni, menu about dan menu keluar aplikasi. Menu topeng kamera terdapat teknologi augmented reality yang dapat menampilkan topeng Cirebon ketika pengguna mengarahkan kamera pada 
wajah, wajah akan terdeteksi ketika seluruh pola wajah terbaca oleh kamera dan akan menampilkan objek topeng Cirebon, terdapat juga menu topeng Cirebon yaitu lima jenis dari topeng Cirebon, pengguna juga bisa mengubah topeng ketika wajah sudah terdeteksi dengan memilih menu topeng Cirebon.

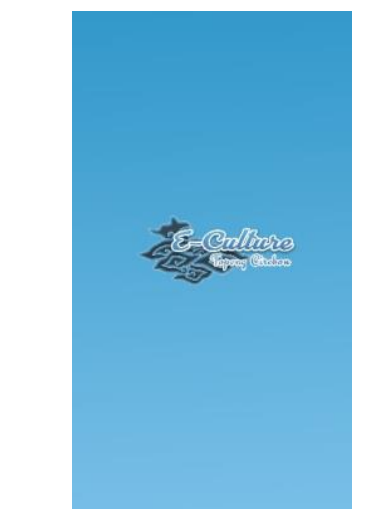

\section{Gambar 10 Splash Screen}

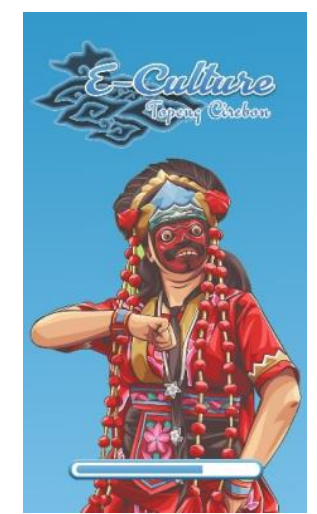

Gambar 11 Loading

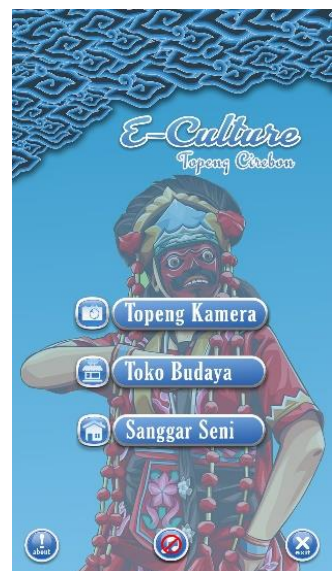

Gambar 12 Menu utama

Berikut adalah tampilan dari setiap menu aplikasi $e$-Culture topeng Cirebon:

\section{Menu Topeng Kamera}

Menu topeng kamera merupakan fitur utama dari aplikasi karena di menu ini terapkan teknologi augmented reality. Pada menu ini terdapat menu yang berisi lima jenis topeng Cirebon, menu topeng di tampilkan secara horizontal dan di tempatkan di bagian bawah. Ilustrasi fitur augmented reality untuk mendeteksi wajah dan menampilkan topeng Cirebon dapat dilihat pada Gambar 13. 


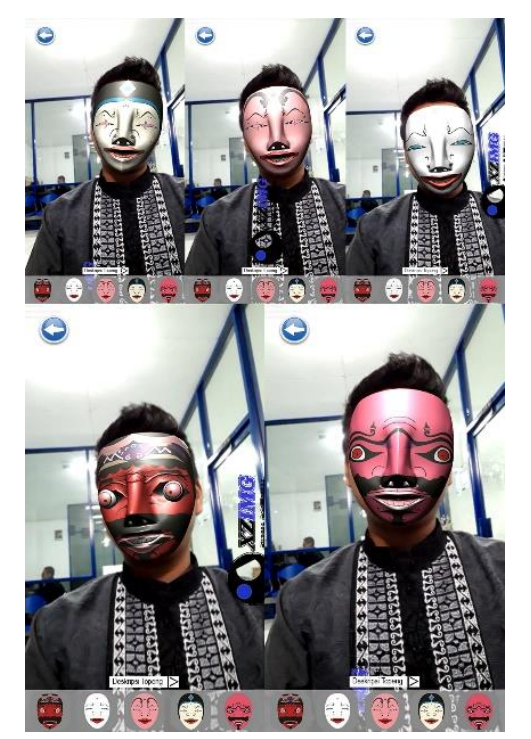

Gambar 13 Ilustrasi augmented reality

Gambar di atas adalah hasil implementasi augmented reality face detection dengan menggunakan library XZIMG. Aplikasi berhasil mendeteksi wajah dan menampilkan objek semua jenis topeng Cirebon dan mengeluarkan suara penjelasan dari setiap topeng mulai dari, panji, samba, rumyang, temenggung, dan kelana.

Menu deskripsi topeng yang terdapat pada menu topeng kamera dapat di lihat pada Gambar 14.

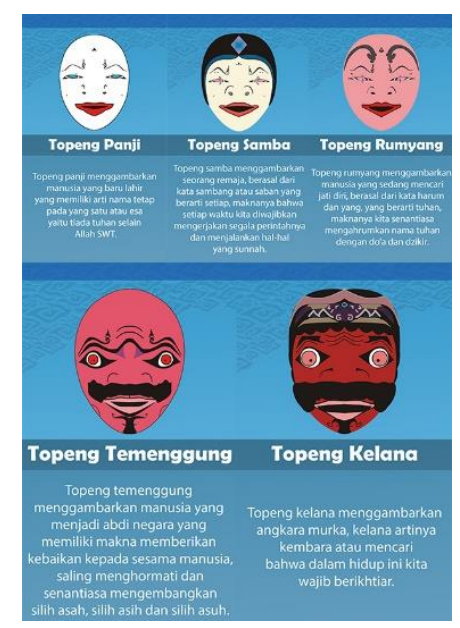

\section{Gambar 14 Deskripsi Topeng}

Gambar di atas adalah menu deskripsi topeng Cirebon yang menjelaskan arti dari masingmasing topeng Cirebon, deskripsi topeng di jelaskan dalam bentuk teks dan gambar, menu ini sebagai alternatif penjelasan topeng Cirebon yang disajikan pada fitur augmented reality topeng Cirebon dalam bentuk audio.

\section{Menu Toko Budaya}

Menu toko budaya merupakan menu yang berisi tentang toko yang menjual souvenir tentang budaya Cirebon seperti gantungan kunci, replika topeng, hiasan dinding topeng Cirebon dan menjual berbagai kebutuhan tari topeng Cirebon dari mulai kostum dan topeng panca wanda. Pada menu ini menampilkan gambar-gambar yang di jual di toko dan menampilkan lokasi toko. Menu topeng budaya dapat di lihat pada Gambar 15. 

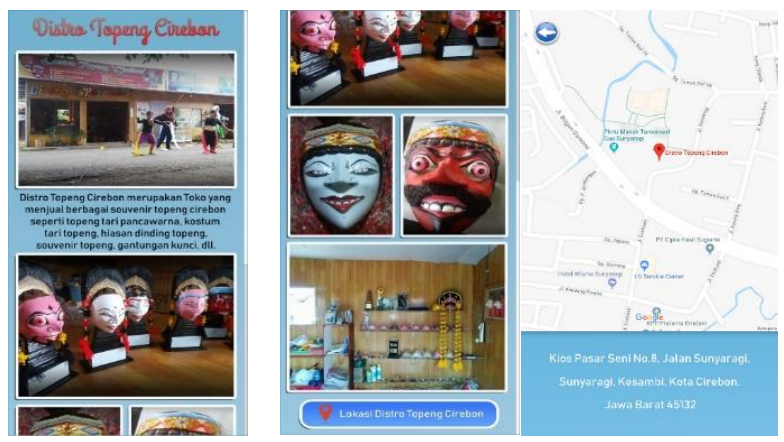

Gambar 15 Menu Toko Budaya

\section{Menu Sanggar Seni}

Menu sangar seni merupakan menu yang berisi tentang informasi sanggar seni tari topeng Cirebon serta lokasi dari sanggar. Menu sanggar seni dapat di lihat pada Gambar 16.

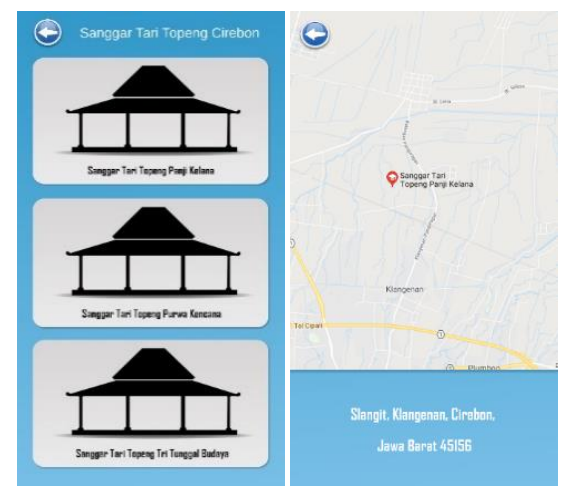

Gambar 16 Menu Sanggar Seni

\section{Menu Tentang Aplikasi}

Menu tentang aplikasi berisi informasi tentang pembuat aplikasi dan versi aplikasi. Menu tentang aplikasi dapat di lihat pada Gambar 17.

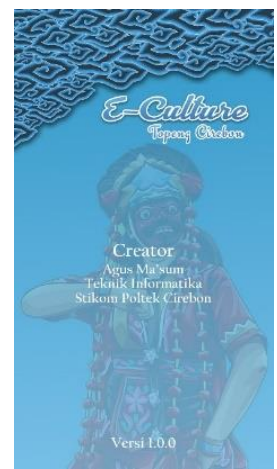

\section{Gambar 17 Menu Tentang Aplikasi}

\section{Implementasi Augmented Reality}

Penelitian ini mengimplementasikan augmented reality sebagai pendukung aplikasi $e$ Culture topeng Cirebon. Dengan menggunakan teknik deteksi wajah dan bisa menampilkan objek topeng ke wajah pengguna aplikasi. Library XZIMG sebagai library untuk pendeteksian wajah[9] dan dapat menampilkan objek topeng Cirebon. Library XZIMG adalah library yang menyediakan deteksi wajah multi platfrom yang membutuhkan masukan 
berupa gambar wajah dan keluaran berupa objek 3D. Berikut adalah beberapa parameter yang terbuka untuk mengatur pendeteksian wajah yang dapat dilihat pada Gambar 18.

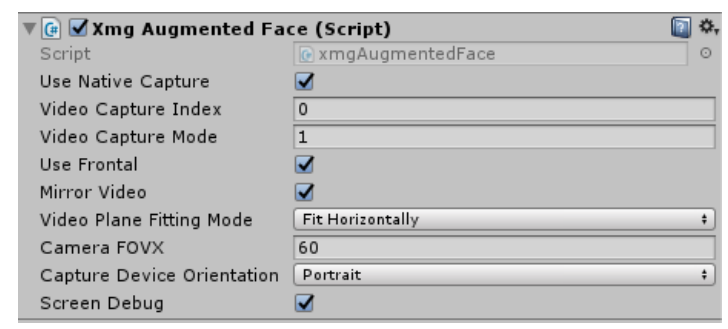

Gambar 18 Parameter Library XZIMG

a) Use Native Capture menunjukkan bahwa aplikasi menggunakan imagity camera texture atau modul pengambilan gambar yang di sediakan oleh library XZIMG.

b) Video Capture Indeks menunjukkan resolusi kamera (0:320x240, $1: 640 \mathrm{X} 480,2$ : 1280x720, $3: 1920 \times 1080$ )

c) Use frontal menunjukkan bahwa aplikasi menggunakan kamera depan jika di buka dengan smartphones.

d) Mirror Video digunakan untuk mengatur posisi objek dan orientasi secara otomatis.

e) Video plane Fitting Mode digunakan untuk mengatur aspek rasio layar.

f) FOVX camera digunakan untuk mengatur pandangan kamera yang digunakan. Nilai default yang digunakan yaitu 60 drajat.

g) Capture Device orientation digunakan untuk mengatur orientasi kamera seperti potrait dan landscape.

\section{d. Customer Test Drives Mock-up}

Customer test-drives mock-up (evaluasi), pemesan mengevaluasi prototype yang telah dibuat dan digunakan untuk memperjelas kebutuhan perangkat lunak. Setelah aplikasi selesai dibuat maka langkah terakhir adalah customer test, dimana aplikasi yang telah dibuat akan diuji oleh customer[10]. Pengujian error guessing tahap pertama dilakukan pada tahap instalasi aplikasi e-Culture topeng Cirebon pada perangkat implementasi dengan spesifikasi minimum. Selanjutnya pengujian error guessing pada aplikasi ini penguji mencoba dengan memilih menu utama. Selanjutnya menguji pendeteksian wajah dengan jarak yang berbeda dan intensitas cahaya yang beda. Pengujian dilakukan sampai tahap akhir yaitu keluar dari aplikasi.

\section{e. Evaluasi}

Berdasarkan hasil pengujian memperlihatkan bahwa aplikasi e-Culture Topeng Cirebon berfungsi dengan baik dari 25 pengujian fungsi yang ada pada aplikasi berhasil berfungsi dengan baik dan jika terdapat error atau bug selanjutnya akan dilakukan maintnance aplikasi.

\section{f. Pengujian Hipotesis}

Setelah dilakukan pengujian didapat hasil pada aspek kegunaan aplikasi yaitu sebanyak $84 \%$ pertanyaan dijawab "ya" yang mengindikasikan bahwa aplikasi menarik dan berguna, kemudian pada aspek penggunaan aplikasi didapatkan hasil sebanyak 80\% pertanyaan dijawab "ya" yang mengindikasikan bahwa aplikasi bermanfaat dan mudah digunakan oleh penggunanya, dan didapat kesimpulan bahwa aplikasi e-Culture Topeng Cirebon dengan menggunakan augmented reality dapat memberikan kemudahan dalam mengenali budaya topeng cirebon. Maka hipotesis yang diajukan oleh peneliti telah berhasil dibuktikan. 


\section{KESIMPULAN}

Berdasarkan penelitian dan uji coba yang dilakukan dapat diambil kesimpulan, penelitian ini berhasil membuat aplikasi $e$-Culture topeng Cirebon sebagai media pengenalan dan pelestarian kebudayaan daerah khususnya daerah Cirebon. Media pengenalan topeng dengan menggunakan augmented reality dapat memudahlan masyarakat dalam mengenali jenis - jenis topeng cirebon. Aplikasi e-Culture topeng Cirebon dengan menggunakan augmented reality dapat memberikan kemudahan dalam mengenali budaya topeng Cirebon.

\section{DAFTAR PUSTAKA}

[1] Avi., 2017. Lestarikan Budaya, Mimi Tumus Masih Menari Topeng di Usia Senja. Diambil kembali dari detik news: https://news.detik.com/berita-jawa-barat/d-3673095/lestarikanbudaya-mimi-tumus-masih-menari-topeng-di-usiasenja?_ga=2.38021795.1407880399.1513343053-449481633.1513343053\#

[2] Haryani, Prita., Triyono, Joko., 2017, "Augmented Reality (AR) Sebagai Teknologi Interaktif Dalam Pengenalan Benda Cagar Budaya Kepada Masyarakat", Jurnal Simetris Volume 8 No 8 ISSN : 2252-4983. Available : https://jurnal.umk.ac.id/index.php/simet/article/view/1614/1131

[3] Pramono, Andy., 2013, "Media Pendukung Pembelajaran Rumah Adat Indonesia Menggunakan Augmented Reality", Jurnal Eltek Politeknik Negri Malang Volume 11 No 1. Available : http://eltek.polinema.ac.id/index.php/eltek/article/view/10

[4] Sejzi, A. A., 2015, "Augmented Reality and Virtual Learning Environment". Journal of Applied Sciences Research, 1-5. Available https://www.researchgate.net/profile/Abbas Abdoli_Sejzi/publication/277137476 Augmen ted_Reality_and_Virtual_Learning_Environment/links/5562ccbe08ae8c0cab3338f3/Augm ented-Reality-and-Virtual-Learning-Environment.pdf

[5] Sitokdana, M. N., \& Tanaamah, A. R., 2016, "Strategi Pembangunan e-Culture di Indonesia". Jurnal Teknik Informatika dan Sistem Informasi JUTISI Volume 2 nomor 2 pp 132-139. Available : http://jutisi.maranatha.edu/index.php/jutisi/article/view/439

[6] Arif., 2016, JENIS SEJARAH KARAKTER TARI TOPENG CIREBON. Diambil kembali dari Dinas Kebudayaan Pariwisata Pemuda dan Olahraga Kabupaten Cirebon: http://disbudparpora.cirebonkab.go.id/jenis-sejarah-karakter-tari-topeng-cirebon

[7] Mustaqbal, M. S., Firdaus, R. F., \& Rahmadi, H. 2015. "Pengujian Aplikasi Menggunakan Black Box Testing Boundary Value Analysis". Jurnal Ilmiah Teknologi Informasi Terapan Volume I No 3. Available : http://jitter.widyatama.ac.id/index.php/jitter/article/view/70/50

[8] Saputra, I. A., \& Mahendra, I. M. 2015. "Optimasi Lintasan Game Mekepung 3D Pada Engine Unity 3D". Jurnal Ilmiah Ilmu Komputer Volume 8 No 2. Available : https://ojs.unud.ac.id/index.php/jik/article/view/18361

[9] Umminingsih., Herawati, Nuniek., Ikhsan, Miftah Nur., 2018, "Detektor Masa Kadaluarsa Produk Menggunakan Smartphone", Jurnal Teknologi Volume 11 No 1. Available : https://ejournal.akprind.ac.id/index.php/jurtek/article/view/1394

[10] Rifa'i, Muhammad., Listyorini, Tri., Latubessy, Anastasya., 2014, "Penerapan Teknologi Augmented Reality Pada Aplikasi Katalog Rumah Berbasis Android", Proseiding SNATIF Ke-1. Available : https://jurnal.umk.ac.id/index.php/SNA/article/viewFile/154/156 